\title{
CHARACTERISTICS OF IMPLEMENTATION EARLY INTERVENTION IN UKRAINE
}

\section{Falasenidi Tereza ${ }^{1}$ \\ Kozak Marta ${ }^{2}$ \\ DOI: http://dx.doi.org/10.30525/978-9934-571-27-5_57}

\begin{abstract}
The purpose of paper is to analyse ukranian expirence and carry out theoretical and methodological analysis of sources related features for the development of early intervention programs and the introduction of early intervention programs in rehabilitation institutions in Ukraine. The importance of providing quality services at the earliest stages of the development of a child with special needs today remains a matter of doubt and is an inalienable right of children, but also of the families in which they are raised. This right is enshrined in international conventions and in national laws already in a number of countries. Defined and justified basic concepts related to this issue. The organization of the Early Intervention System in Ukraine, which we have reviewed, confirms that today, Early Intervention, by virtue of its significant advantages, is an important socio-economic strategy for the development of society and thus an integral part of state policy. The establishment of a regulatory framework governing the activities of early intervention services, as well as the adoption of appropriate laws at the national or federal level, enables the effective management of the early intervention program at all levels from city and district to state level.
\end{abstract}

\section{Introduction}

Creating an early intervention system is an urgent component of reforming the health system, which aims to strengthen the primary care unit. Early intervention is a system of early detection and early special medical and psychological-pedagogical assistance for children with developmental disabilities, their parents and professionals working with this group of children, and includes

${ }^{1}$ Candidate of Pedagogical Sciences,

Assistant Lecturer at Department of Sociology and Social Work,

Lviv State University, Ukraine

${ }^{2}$ Candidate of Biological Sciences,

Assossiated Proffesor at Department of Sociology and Social Work, Lviv State University, Ukraine 


\section{Characteristics of implementation early intervention in Ukraine}

the timely diagnosis of the child, the definition of his special psychological and educational needs in order to effectively overcome and correction of deviations in the development of the child from the first days of life. According to the international classification, early intervention requires mainly the following groups of children: children with intellectual disabilities, with visual and hearing impairments, movements, with communication and language problems, with autism, with behavioral disorders. This group includes, among others, children of biological and social risk: preterm and low-risk, after intrauterine infections or severe birth injuries, as well as children whose parents cannot provide them with the necessary developmental conditions: children of adolescent mothers, children illiterate poor parents, children of mentally ill mothers, children subjected to domestic violence. It aims to improve access to comprehensive, long-term services for early childhood with mental-physical impairment, the risk of their occurrence, and the families that bring such children. The establishment of early intervention services in the near future will promote the strengthening families who raise children with special needs and preventing the child's reintegration, taking systematic preventive measures to prevent childhood disabilities. In the long run, such activities will allow child with special needs to be social included, decrease the expenditures for special education and care. The Early Childhood Intervention Service is a comprehensive service designed to unite multidisciplinary "scattered" care (medical, rehabilitation, psychological, psychotherapeutic, speech therapy, social) into a single organizational system that clearly identifies the various painful moments of everyday child's life and family, identify and provide the necessary reasonable assistance. Establishing such a system in Ukraine will initiate the unification of institutions that will be able to assess the early development of the child and provide relevant services. Early intervention is directed not only on rehabilitation process, but also to prevent violations. This service is provided not only for children with long-term violations, but also for children at risk. The practice of providing early intervention services to young children with a disorderly health and development and the risk of their occurrence and their families will be implemented at the level of administrative-territorial units of the Transcarpathian, Lviv, Odessa and Kharkiv regions. These services have already begun in communal institutions of health care, education, social and non-governmental organizations.

It should be noted that in recent decades the development of the theory and practice of Early Intervention was based on: 


\section{Falasenidi Tereza, Kozak Marta}

1. the formation of new conceptual frameworks that unite previously disconnected sectors and sectors of knowledge, such as medicine, education, social sciences, and, in particular, psychology;

2. the transition from forms of intervention spread at child and the elimination of an illness to the involvement family, the local community and others systems joined with the development of the child;

3 . inclusion in the target group not only children with obvious or established signs of developmental delays, but also children at risk of their occurrence. This concerns not only the risk associated with the presence of a specific diagnosis or biological risk, but also the social risk associated with the environment or environment, such as deprivation or lack of stimulation, neglect of parental responsibilities, violence, and others;

4.the transition to a functional classification, in particular the International Classification of Functioning (ICF) recommended by the WHO (2001) [4].;

It is important to note that the ICF proceeds from the identification and categorization of violations to the description of the impact of these violations on the activity of the individual and its participation in society.

Thus, the Early Intervention model was formed on the basis of scientific research, clinical and practical experience in various disciplines such as, for example, maternal and child health, preschool education, special pedagogy, developmental psychology and neurobiology, as well as under the influence of development and the spread of the movement of parents of children with special needs. This model offers new theoretical concepts and practical approaches to understanding the problems and needs of infants and young children with developmental delays, as well as their families [5].

The main differences between today's model of Early Intervention from traditional services based on a medical model are presented in Table 1.

Early intervention is a system of services that helps babies and toddlers with developmental delays or disabilities. Early intervention focuses on helping eligible babies and toddlers learn the basic and brand-new skills that typically develop during the first three years of life, such as:

- physical (reaching, rolling, crawling, and walking);

- cognitive (thinking, learning, solving problems);

- communication (talking, listening, understanding);

- social/emotional (playing, feeling secure and happy); and

- self-help (eating, dressing). 
Characteristics of implementation early intervention in Ukraine

Table 1

\begin{tabular}{|l|l|l|}
\hline \multicolumn{1}{|c|}{ Characteristics } & \multicolumn{1}{|c|}{ Tradition model } & \multicolumn{1}{c|}{ Early Intervention } \\
\hline $\begin{array}{l}\text { Inclusion in } \\
\text { program }\end{array}$ & $\begin{array}{l}\text { Children with obvious } \\
\text { / established signs of } \\
\text { developmental delays }\end{array}$ & $\begin{array}{l}\text { Children with developmental } \\
\text { delays or at risk }\end{array}$ \\
\hline Early detection & $\begin{array}{l}\text { Deferred to the child's } \\
\text { involvement into program }\end{array}$ & At the earliest stages \\
\hline Classification & $\begin{array}{l}\text { Identification and } \\
\text { categorization of disorders }\end{array}$ & $\begin{array}{l}\text { Functional, describes the effect of } \\
\text { disability on human activity and its } \\
\text { participation in society }\end{array}$ \\
\hline Focus & Child as defective carrier & Family \\
\hline Goal & $\begin{array}{l}\text { "Normalization" of child, } \\
\text { elimination of a defect }\end{array}$ & $\begin{array}{l}\text { Normalizing the life of child and } \\
\text { family, preventing the emergence } \\
\text { of restrictions on activity, the } \\
\text { development of strengths, new } \\
\text { skills and independence }\end{array}$ \\
\hline
\end{tabular}

\section{Legislation in the implementation system of early intervention in Ukraine}

The National Human Rights Strategy, approved by the Decree of the President of Ukraine dated August 25, 2015, No. 501/2015, establishes and ensures the functioning of the early intervention services system with aim to create favorable living conditions for children with developmental disorders, supporting families in which they are raised, prevention of parents' refusal from children who have development disorder, disability of the children's population.

According to paragraph 2.1 of the Plan of Activties for the Implementation in 2015 of the National Program "National Action Plan for the Implementation of the UN Convention on the Rights of the Child" for the period up to 2016, approved by the Cabinet of Ministers of Ukraine from 08.08.2015 № 881 entrusted the pilot introduction into the medical practice of providing services of early intervention to support families educating children with developmental problems, preventing the parents from refusing children with mental and physical disorders and getting them into orphanages, as well as disability of children's population.

The task to develop early intervention in Ukraine was documented in the Recommendations of the Parliamentary Hearings on the topic: "Education, health care and social welfare of children with disorders of psychophysical development: problems and the ways of their solution", 
which are fixed by the Resolution of Ukrainian government dated January 13, 2015 No. 96- VIII.

The introduction of early intervention services in Ukraine is a scientific, practical and methodological basis, which was fixed in the resolution of the Presidium of the National Academy of Medical Sciences of Ukraine dated 22.11.2012 № 26/2 “On the establishment of an early intervention system in Ukraine for the rehabilitation of children in the first years of life".

The importance of the development early intervention in Ukraine was also confirmed by studies by the World Bank office in Ukraine "Early development of children with special needs in Ukraine. Situation Analysis and Further Recommendations" held in 2014 by SOFT Tulip with the involvement of the public sector.

The Government approved a plan for the implementation of a pilot project on the practice of early intervention services for children in 2017-2020, supported by the Ministry of Health. Order of the Cabinet of Ministers of Ukraine, December 14, 2016 No. 948-p "Some issues of the implementation of the pilot project" Creation of a system of early intervention services provision "for the development of child, preserving its health and life".

\section{Analysis of child's population with psychophysical impairment}

Taking into account the above, comparing the number of children 0-3 years old in Ukraine with an international indicator of the number of children requiring early intervention services ( $13 \%$ of children), it is estimated that today more than 246 thousand children from 0-3 years of age are in need of appropriate services. Most of these children live in Donetsk (20642 children) and Dnipropetrovsk (18,800 children), Kyiv (17,459 children), Lviv (15,315 children), and Odesa (15,286 children), the smallest - in Ternopil (6,163 children), Chernivtsi (5949 children), Kirovograd (5481 children), Sumy (5,437 children) and Chernihiv (5,103 children) regions [6].

At the same time, according to investigation of the World Bank office in Ukraine, "Early development of children with special needs in Ukraine. Situation Analysis and Further Recommendations", conducted in 2014 by the international organization SOFT Tulip with the involvement of public sector, the number of early childhood with disability in the Kharkiv region is $3.5 \%$, in Odesa $-3.6 \%$, in the Lviv region $-2,8 \%$. Such discrepancies testify about the imperfection of preventive examinations, including outdated methodologies, and lack of necessary knowledge of the staff [5]. 
For 25 years of independence in Ukraine, the number of children with disabilities has more than doubled - from 72086 people at the beginning of 1991 to 151125 people at the beginning of 2015 (indicator 198.5 per 10 thousand children population).

Every year in Ukraine more than 16 thousand children are firstly diagnosed with a disability. In 2014, for the first time, 16,250 people became disabled $10.8 \%$ of the total number of children with disabilities (an indicator of 21.3 per 10 thousand children).

The most disabling diseases are birth defects, deformities and chromosomal abnormalities, diseases of the nervous system, mental disorders and behavior. The largest number of children who for the first time in 2014 became disabled in Dnipropetrovsk (1 321 children), Lviv (1 203 children) and Kyiv (1 017 children), the smallest - in Kirovograd (407 children), Sumy (409 children) and Chernivtsi (433 children) areas.

The share of children with disabilities in the overall structure of children over the period increased from $0.5 \%$ to $1.98 \%$ (according to international data, the share of children with disabilities is more than $5 \%$, of which $0.7 \%$ have severe disabilities).

At the same time, according to the calculations of the European Academy of Children with Disability in Ukraine, about one million children need constant medical and pedagogical support. Also according to research in various European countries $18 \%$ of children under the age of 1.5 years can suffer from mental illness that is associated with the risk factors in the early childhood.

\section{Rehabilitation centers in system of early intervention}

To date, thousands of institutions and institutions of the healthcare, education, social protection and non-governmental organizations focus on providing various services to children with disabilities and their families.

There are currently 159 rehabilitation institutions for people with disabilities in Ukraine (table 2).

Only 1 rehabilitation center works in Kropyvnytckyj, Kharkiv. There are 2 establishments in Vinnytsya, Transcarpathian, Rivne and Volyn regions. There are 3 establishments in Dnipropetrovsk oblast, 4 centers in Chernihiv and Kherson regions. Zaporizhzhya, Odessa, Poltava regions have 5 centers. There are 6 centers in Chernivtsi, Kyiv and Ivano-Frankivsk regions. Zhytomyr, Cherkasy and Ternopil regions employ 8 rehabilitation centers. Donetsk 


\section{Falasenidi Tereza, Kozak Marta}

region is represented by 22 rehabilitation centers; Lviv 11 institutions, Lugansk 18, Mykolaiv 12 centers, Sumy 13 centers, and 17 rehabilitation centers are operating in Khmelnytsky region. There are 12 centers in Kyiv.

At the same time, these centers do not constitute a single integrated system that would ensure proper inter-sectoral coordination and interaction in terms of meeting the needs of the appropriate category of children and their legal representatives. In such institutions and centers, for the most part, there is no adequate material and technical base and trained professionals; they work out of outdated programs and techniques. This is accompanied by the territorial inaccessibility of individual institutions and centers, due to their remoteness and uneven presence in the regions.

The rehabilitation center of mixed type (complex rehabilitation) for people mental disabilities, that was approved by the order of the Ministry of Social Policy on February 15, 2016, No. 112, says that purpose of center is to carry out a complex of rehabilitation measures aimed at creating conditions for the comprehensive development of people with disabilities due to intellectual disorders, as well as children under the age of 2 who are at risk of getting a disability, their knowledge, skills, achieve and maintain their maximum independence, physical, mental, social and professional skills in order to realize personal potential.

The center provides:

- implementation of the norms and provisions defined by the Convention on the Rights of Persons with Disabilities, the Laws of Ukraine "On the Basics of Social Protection of the Disabled in Ukraine", "Rehabilitation of Disabled People in Ukraine" [3], "Social Services" [2], "Psychiatric care" [1], Decrees of the Cabinet of Ministers of Ukraine dated January 31, 2007 No. 80 "On Approval of the Procedure for the Provision of Rehabilitation Services to Adult and Children with Disability", regarding the provision of the rights of persons for rehabilitation with the view of their further integration into society; creation of conditions for reduction and overcoming intellectual and physical impairment, prevention of such impairment, correction of development, formation and development of basic social and everyday skills;

- creation of conditions for preventing and preventing discrimination of persons, in particular by ensuring reasonable accommodation;

- development of skills of independent life in society with necessary support, formation of stereotypes of safe behavior, mastering skills of protection own rights, interests and positive perception of oneself and others; 


\section{Characteristics of implementation early intervention in Ukraine}

- provision of social services during the rehabilitation process;

- preparation of parents or legal representatives of individuals for the continuation (if necessary) of rehabilitation measures outside the institution;

- carrying out a complex of rehabilitation measures in accordance with individual plans of rehabilitation, composed, in particular, with the aim of implementing individual rehabilitation programs involving individuals and, if necessary, their parents or legal representatives to participate in this process;

- carrying out activities, in particular on professional orientation, skills acquisition by persons, including workshops, identification of their opportunities for vocational training in appropriate educational institutions, vocational rehabilitation centers (day-time employment);

- assistance in the establishment of guardianship or care in the event of the recognition of a person incapacitated or if its capacity is limited;

- cooperation with domestic and foreign rehabilitation, educational, medical, scientific enterprises, institutions and public associations [6].

These institutions and centers of various spheres of activity work on the basis of the staff principle "within the competence", that is, when educators, doctors and social workers provide services separately from each other in different premises, provided that they will come and almost none of these institutions and centers do not provide an interdisciplinary approach. In this case, there are cases where the same types of services are provided by institutions of various spheres, and some types services - not provided at all. There is no systemic "inheritance" between institutions and centers - the child reaches a certain age, therefore, it cannot already receive the necessary services where it received them before, and then child has no place to go.

In Ukraine, since 1996, the establishment and development of a network of rehabilitation centers for children with disabilities (social protection system), educational and rehabilitation centers (educational system), centers for medical and social rehabilitation of children (health care system) has been launched.

Currently, early intervention services for children with developmental disabilities are provided only by individual institutions and institutions primarily operating with non-governmental organizations at the expense of international support and sponsorship and charitable contributions. 


\section{Information}

Table 2

the number of rehabilitation institutions for people with disabilities in the system Ministry of Social Policy

(in terms of administrative-territorial units) on 1 January 2015

\begin{tabular}{|c|c|c|c|c|c|c|c|c|c|c|c|c|c|c|c|c|c|c|}
\hline \multirow[b]{2}{*}{ № } & \multirow[b]{2}{*}{ Province } & \multirow{2}{*}{ 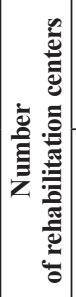 } & \multicolumn{6}{|c|}{$\begin{array}{c}\text { Centers for Social } \\
\text { Rehabilitation } \\
\text { of Children with } \\
\text { Disabilities }\end{array}$} & \multicolumn{5}{|c|}{$\begin{array}{l}\text { Centers of mixed } \\
\text { type for disabled } \\
\text { and disabled } \\
\text { children }\end{array}$} & \multicolumn{5}{|c|}{$\begin{array}{c}\text { Mixed-type } \\
\text { centers for adult } \\
\text { and children with } \\
\text { mental retardation }\end{array}$} \\
\hline & & & 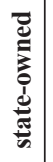 & : & : & : & 苞 & 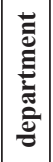 & 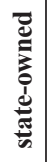 & : & ? & 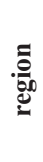 & हٓ & 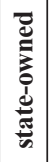 & : & ? & . & 홍 \\
\hline 1 & \begin{tabular}{|l|} 
Vinnitsa \\
\end{tabular} & 2 & 1 & & & & 1 & & & & & & $\mathbf{0}$ & & & & & $\mathbf{0}$ \\
\hline 2 & Volyn region & 2 & 1 & & 1 & & 2 & & & & & & $\mathbf{0}$ & & & & & $\mathbf{0}$ \\
\hline 3 & Dnipropetrovsk & 3 & & 1 & 1 & & 2 & 1 & & & & & $\mathbf{0}$ & & & & & $\mathbf{0}$ \\
\hline 4 & Donetsk & 22 & & & 16 & 3 & 19 & 1 & & & & & $\mathbf{0}$ & & & & & $\mathbf{0}$ \\
\hline 5 & Zhytomyr & 8 & & 1 & 4 & 3 & 8 & & & & & & $\mathbf{0}$ & & & & & $\mathbf{0}$ \\
\hline 6 & Transcarpathian & 2 & & & & & $\mathbf{0}$ & & & 1 & & 1 & 2 & & & & & $\mathbf{0}$ \\
\hline 7 & Zaporozhye & 5 & & 1 & 1 & 1 & 3 & & & & 1 & & 1 & & & & & 0 \\
\hline 8 & Ivano-Frankivsk & 6 & & 1 & 2 & 3 & 6 & & & & & & $\mathbf{0}$ & & & & & $\mathbf{0}$ \\
\hline 9 & Kyivska & 6 & & & 2 & & 2 & 1 & & & 1 & 1 & 2 & & & & & $\mathbf{0}$ \\
\hline 10 & Kirovograd & 1 & & & 1 & & 1 & & & & & & $\mathbf{0}$ & & & & & $\mathbf{0}$ \\
\hline 11 & \begin{tabular}{|l} 
Lugansk \\
\end{tabular} & 18 & & 1 & 8 & 5 & 14 & 3 & & & & & $\mathbf{0}$ & & & & & $\mathbf{0}$ \\
\hline 12 & Lviv & 11 & & 1 & 1 & 7 & 9 & & & & 1 & & 1 & & & & & $\mathbf{0}$ \\
\hline 13 & Mykolaiv & 12 & 1 & & 3 & 8 & 12 & & & & & & $\mathbf{0}$ & & & & & $\mathbf{0}$ \\
\hline 14 & Odesa & 5 & & & 1 & & 1 & 2 & & & & & $\mathbf{0}$ & & & 1 & & 1 \\
\hline 15 & Poltava & 5 & & & 4 & 1 & 5 & & & & & & $\mathbf{0}$ & & & & & $\mathbf{0}$ \\
\hline 16 & Rivne & 2 & & & 1 & & 1 & & & & & & $\mathbf{0}$ & & & & & $\mathbf{0}$ \\
\hline 17 & Sumy & 13 & & 1 & 5 & 6 & 12 & & & & & 1 & 1 & & & & & $\mathbf{0}$ \\
\hline 18 & \begin{tabular}{|l|} 
Ternopil \\
\end{tabular} & 8 & & 1 & 1 & 6 & 8 & & & & & & $\mathbf{0}$ & & & & & $\mathbf{0}$ \\
\hline 19 & Kharkiv & 1 & & & & & $\mathbf{0}$ & & & & 1 & & 1 & & & & & 0 \\
\hline 20 & Kherson & 4 & & 1 & 2 & 1 & 4 & & & & & & $\mathbf{0}$ & & & & & $\mathbf{0}$ \\
\hline 21 & Khmelnitsky & 17 & & & 4 & 12 & 16 & & & & & & $\mathbf{0}$ & & & & & $\mathbf{0}$ \\
\hline 22 & Cherkasy & 8 & & & 3 & 4 & 7 & & & & & & $\mathbf{0}$ & & & & & $\mathbf{0}$ \\
\hline 23 & Chernivtsi & 6 & & 1 & & 3 & 4 & & 1 & & & & 1 & & & & & 0 \\
\hline 24 & Chernihiv & 4 & & 1 & 2 & 1 & 4 & & & & & & $\mathbf{0}$ & & & & & $\mathbf{0}$ \\
\hline 25 & Kyiv & 12 & & & & & $\mathbf{0}$ & 10 & & & 1 & & 1 & & & & & $\mathbf{0}$ \\
\hline \multicolumn{2}{|c|}{ Total } & 183 & 3 & 11 & 63 & 64 & 141 & 18 & 1 & 1 & 5 & 3 & 10 & $\mathbf{0}$ & $\mathbf{0}$ & 1 & $\mathbf{0}$ & 1 \\
\hline
\end{tabular}

Since November 2014 on the territory of Ukraine, where the authorities do not temporarily exercise or exercise their powers in full, 7 centers for social rehabilitation for disabled children remain in the Donetsk region and 9 such rehabilitation institutions are located in the Luhansk region and the Luhansk interregional center of professional rehabilitation disabled people 


\section{Characteristics of implementation early intervention in Ukraine}

\section{Conclusion}

Creation and implementation of an early intervention system in Ukraine taking into account international standards and best practices should include:

- the formation of the state policy, including by creating the necessary legislative framework (definition of the term and essence of early intervention, sources of financing of the relevant services and general principles), as well as approval of regulatory acts that would determine the qualitative and quantitative indicators of early intervention services, sub objects and facilities that provide and receive such services, mechanisms of their interaction, norms of the number of employees, etc.;

- Providing interagency and interdisciplinary approaches at all stages of the functioning of the early intervention system, which requires the involvement and interaction of institutions and institutions of the health care system, education, social welfare, public organizations as well as parents themselves;

- the establishment of a network of centers, offices, offices of early intervention, which will maximally territorially approach the homes of families with children with developmental abuses and mobile services for the provision of appropriate services primarily to children living in rural areas;

- Early detection of children with developmental disabilities and at risk of such violations, risk group children with social protection specialists, including interaction with health and education professionals. It involves the use of home visits and patronage systems, shifting the focus from monitoring to family support;

- development of training programs, trainings and advanced training courses, training of appropriate personnel.

\section{References:}

1. Psychiatric Aid: Law of Ukraine from 22.02.2000 № 1489-III Information from the Verkhovna Rada of Ukraine. 2017, № 34, p. 47.

2. Social Services: Law of Ukraine from 19.06.2003 № 966-IV-3 Information from the Verkhovna Rada of Ukraine. 2018, p. 12.

3. The Rehabilitation of People with Disability in Ukraine: Law of Ukraine from 10.11.2015 № 766-VIII Information from the Verkhovna Rada of Ukraine. 2017. p. 36.

4. International Classification of Functioning, Disability and Health World Health Organization, 2001. Retrieved from: http://apps.who.int/iris/bitstream/10665/85930/ 1/9241545445 rus.pdf. accessed mode 01.03.2018.

5. Early development of children with special needs in Ukraine. Situation analysis and further recommendations (2014), Kyiv: Study of the World Bank Office in Ukraine, p. 46.

6. Statistical collection (2015) Protecting children who need a special attention of society, Kyiv: Gosstat, p. 78. 